\title{
Az okoseszközök használata kognitív idegtudományi nézőpontból
}

\author{
Csépe Valéria ${ }^{1}$ és Török Ágoston ${ }^{2}$ \\ ${ }^{1}$ TTK Agyi Képalkotó Központ, Budapest \\ ${ }^{2} A G T$ Group RED, Darmstadt
}

\begin{abstract}
Absztrakt
A szerzők az okoseszközök használatát megalapozó kognitív tényezők változásának néhány jellemzőjét bemutatva a 21. század oktatási lehetőségeit és kihívásait elemzik. A tanulmány kitér a digitális eszközök használatának kezdeti szakaszaira, az okostelefonok alkalmazásának lehetséges előnyeire, akadályaira, valamint veszélyeire. A tanulás neurális alapfolyamatainak bemutatásából kiinduló elemzés bemutatja az okoseszközök használatát kísérő agyi változások szisztematikus kutatásának feltételeit, az összefüggések tudományos szigorúsággal feltárandó tényezőit. Az alapkészségek fejlődését és eltéréseit meghatározó agyi változások vizsgálatából származó adatok és az azokra épülő modellek megbízhatóságát a szerzők az olvasás és szövegértés, a korai matematika, valamint a zenei nevelés területén kiemelve számos példát mutatnak be arra vonatkozóan, miért kevés a megbízható idegtudományi adat az okoseszközökkel támogatott tanulásra vonatkozóan. Külön kitér a tanulmány a függőségekre, valamint az okoseszközök használatát megalapozó kognitív és motivációs tényezőkre. A tanulmány a virtuális valóság és a gamifikáció típusú oktatási módszerek területén feltárandó ismeretek bemutatásával hangsúlyozza, hogy az agyi hálózatok változásában mérhető hatást ezen a területen miért ismerjük kevésbé, mint a tanulás más faktoraival kapcsolatban.
\end{abstract}

Kulcsszavak: okostelefon, virtuális valóság, gamifikáció, agyi plaszticitás

Az oktatás digitális átalakulása összetett, nagyobb időtávlatban megvalósuló változás, s nem egyszerüen oktatásmódszertani kérdés. A változás egyszerre jelenti az oktatás tartalmának, tárgyának és módszereinek átalakulását. A 2018-as közgazdasági világfórumon még komoly viták folytak arról, hogy miként kellene az ismeretalapú oktatásnak átalakulnia, s milyennek kellene lennie az olyan tudásnak, amely sikeresen alkalmazható az erőteljesen digitalizálódó világban. Már ekkor jól látható volt, hogy olyan változások várhatók a világban, amelyekre az oktatásnak is reagálnia kell, sőt proaktívan fel is kell készítenie a jövőre a következő nemzedékeket. A Nemzeti alaptanterv 
és a kerettantervek fejlesztésénél ${ }^{1}$ a programozástól a digitális biztonságig minden lényeges területet magában foglaló Digitális kultúra tantárgy több és más, mint a főleg Közép- és Kelet-Európában meghonosodott, s az elmúlt évtizedben alig változó Informatika tantárgy. A szükséges ismeretek mellett olyan készségek és kompetenciák kialakítására helyezi a hangsúlyt, amelyek az aktív tanulásban és a digitális oktatásban való részvételhez elengedhetetlenek. A tanulási terület eltérő ütemben fejlődött az egyes iskolákban, ennek sokféle okát itt most nem elemezzük.

A tanulmány megírásának időpontjában Magyarország a COVID-19 járvány második szakaszát éli, s csaknem két hónapja folyik digitális tanrendben az oktatás. A pedagógusok és a tanulók igen nagy többsége sikeresen oldotta meg ezt a rendkívül új és jelentős alkalmazkodást igénylő feladatot. Bebizonyosodott az is, hogy a megfelelően fejlett digitális kompetenciákkal rendelkezők nagyobb problémák nélkül, gyorsan álltak át a digitális jelenlétet biztosító programok használatára, a tanítás és tanulás szervezésének sokféle formájára, köztük a digitális térben történő egyéni foglalkozásra is. Pedagógusaink új tanulástámogató programokat próbáltak ki, s az aktív tanulás minden korábbinál erőteljesebben jelent meg. Tény az is, hogy sok tanuló lehet vesztese a digitális lemaradásnak, az eszköz- és készséghiánynak. A tapasztalatok összegzése, értő elemzése, igen fontos feladat lesz, s ehhez a normál mederbe visszatérő tanítás-tanulás világában is megtartható és megtartandó digitális tanítási-tanulási módszerek feltérképezése megkezdődött. Fontos, hogy továbbra is alkalmazhatók legyenek az újonnan szerzett vagy fejlődő, megerősödő kompetenciák, s fontos lehet a digitális eszközök, mindennapi nevükön a kütyük iránti attitűd változása is.

A világ az elmúlt száz évben rendkívül sokat változott. Az is igaz, kicsit sarkítva, hogy ehhez a változáshoz képest az oktatás hagyományos formája, s benne az elterjedten használt, frontális oktatásként emlegetett tanítás, szinte minimális megújulást mutat hosszú ideje. Az örökzöld kérdés az, hogy hogyan lehet az oktatásnak a változásokhoz alkalmazkodnia és színvonalában úgy javulnia, hogy a költségek ne emelkedjenek jelentősen. Ez különösen igaz a digitális eszközök esetében, amelyeknek készségszintű használata ma már nem csupán elvárás, hanem a személyre szabott oktatás nagyszerű lehetősége. Bloom klasszikus eredménye (Bloom, 1984) csaknem négy évtizeddel ezelőtt azt igazolta, hogy az egyéni foglalkozás (tutoriális) hatása jelentős, s az ilyen foglalkozásban is résztvevő tanulók jobban teljesítettek, mint az adott osztály tanulóinak 98\%-a. Ez azért lehetséges, mert ez a forma az oktatás személyre szabásának legkézenfekvőbb módja. Ennek egy korszerủbb, s elterjedt formája azoknak az úgynevezett masszív online tanulási platformoknak a megjelenése, amelyek többek között videókkal támogatják a tanulást. Az oktatás digitalizációját azonban szinte minden országban ide-

${ }^{1}$ Az EFOP 3.2.15. konzorcium taralomfejlesztési projektjének egyik feladata, bővebben lásd az EKE Oktatás 2030 oldalán. 
genkedés kísérte, s a 2000-es évek óta növekvő szakadék a tanulók és a pedagógusok eszközhasználati készségei között nem hatott ösztönzően a digitális pedagógiai módszertan térnyerésére.

\section{A digitalizáció kezdeti lépései}

A digitalizáció első formáinak megjelenését a számítógépes prezentációk jelentik. A prezentációk diasorainak elkészítése és bemutatása azonban önmagában nem elegendő a digitális világ értő használatához és a kor kihívásaihoz illeszkedő oktatáshoz. Ez nem csupán annak köszönhető, hogy a prezentáció nem aktív tanulói használatot igénylő módszer, bár az oktatásban a felsőtagozatban gyakran alkalmazott tanulói prezentáció ez alól kivétel. A pedagógusok munkájában alkalmazott prezentációk elterjedésével egyidejűleg megjelent az a jól észlelhető változás, amely a motivációra hat, s egyben a megértéshez és az emlékezeti felidézéshez szükséges tanulás mélységét is veszélyezteti. Az úgynevezett „prezentáció általi halál” kifejezés (Taylor, 2007) azt a jelenséget írja le, amely a prezentáció öncélú, a tanulót lekötni, megragadni nem képes használatának a következménye. Ez a fajta prezentáció nem csupán nem segíti a megértést, hanem a tudás megszerzésére irányuló motiváció teljes elvesztéséhez is vezet. Ennek hátterében többek között a prezentációkészítés oktatásának hiánya áll. Ehhez hozzájárulhat az is, hogy az internetről akár ingyenesen le lehet tölteni olyan szoftvereket, amelyek használata egyszerü, így bárki rövid idő alatt prezentációt tud készíteni. Egy néhány éve lefolytatott kutatásban, kvalitatív interjúkban diákok prezentációk és az iskolában történő laptophasználat iránti attitűdjét mérték fel (Blikstad-Balas, 2015). A kutatók azt találták, hogy a tanulók a diasorokra alig vagy egyáltalán nem fordítottak figyelmet. Ennek okaként egyrészt a prezentációk „unalmasságát”, másrészt azok későbbi elérhetőségét nevezték meg. Ez utóbbinak viszont az a veszélye, hogy a tanuló a későbbi használat során, ismereteit csak a diasorokon fellelhető információkra építi, holott a tananyag a diasorokból és a helyszínen hozzájuk füzött, a megértést segítő magyarázatból áll (Blikstad-Balas, 2015).

A világ gyorsuló változásának és az információk folyamatos bővülésének egyik következménye az úgynevezett lemaradási jelenség. Ennek oka lehet, hogy a tananyagot a tanuló nem érti, a pedagógus az osztálytermi munkában nem tud neki segíteni a jobb megértésben, esetleg a magyarázat túl bonyolult, vagy a tanuló nem tesz fel kérdést, nem jelzi semmilyen formában, hogy nem érti az aktuális témát. Ez a probléma különösen gyakran jelenik meg az MTMI (matematika, természettudomány, mérnöki tudományok és informatika) területeken (Kim, Belland \& Walker, 2017). Itt jelentős szerepe lehet a számítógéppel támogatott felzárkóztatásnak, azaz a félautomatikusan vagy teljesen automatikusan támogatást biztosító szoftverek használatának a téma megértésében. Egy átfogó elemzés statisztikai módszerekkel hasonlította össze a témában született hatásmérő tanulmányokat, és azt mutatta 
ki, hogy a számítógéppel támogatott felzárkóztatás jelentős hatással van a problémaalapú tanulás kognitív kimeneti változóira az MTMI területeken (Kim, Belland \& Walker, 2017). Azt is kimutatták, hogy attól függően, milyen típusú volt a felzárkóztatás, milyen módszert alkalmaztak és ez milyen területen történt, a hatásméret a kicsitől a közepesig változott.

Az itt említett alkalmazások és veszélyek önkényesen kiragadott példák. Mindössze azt hivatottak illusztrálni, hogy az előzmények sokfélék, negatív és pozitív tapasztalatok is övezik. A 21. század második évtizedében azonban a digitális eszközök, tanulást támogató programok használata megkerülhetetlen, sőt gyakran nélkülözhetetlen az oktatásban, s a digitális kompetencia az iskola és a munka világában is az előmenetelt és érvényesülést meghatározó tényező. Nem hagyhatjuk ugyanakkor figyelmen kívül, hogy a digitális eszközök és módszerek hatását egyszerre övezi pozitív várakozás és ellenállás is. Ez különösen erőteljesen nyilvánul meg a mobiltelefonok iskolai használatával szemben, s nem szabad arról sem megfeledkeznünk, hogy a számítógépek káros hatásától is sokan tartanak. Az internethasználat, az ellenőrizhetetlen applikációk, a közösségi média veszélyei valósak. Nem véletlen ezért, hogy a Digitális kultúra tantárgy erre az összetett, értést és értelmezést egyaránt igénylő világra kívánja felkészíteni a tanulókat. Felmerül gyakran az a kérdés is, hogy a digitális világ miként hat az egyéni tudás fejlődésére és a gyermeki agyra. A tanulmány további részében négy olyan kérdéssel foglalkozunk, amellyel kapcsolatban a laikus tudás gyakran téves értelmezésekhez vezet.

\section{Az okoseszköz-használat kognitív és motivációs háttere}

Az okoseszközök közül a tanulók legelterjedtebben a mobiltelefonokat használják. A pedagógusok azonban többnyire azzal a mobilhasználattal találkoznak, amely a tanulók figyelmét elvonja a tanulástól, az órai munkától. A chat, a közösségi média különböző platformjain tapasztalható jelenlét elvonja a figyelmet, s a digitális eszközöket alig alkalmazó osztálytermi órák már nem adnak elegendő élményt. A vizualitás új világában felnőtt generációt az élmény, a tapasztalat és a személyes aktivitás hiánya egyre jobban távolítja attól, hogy mentálisan is jelen legyen az órán. Nem véletlen tehát, hogy az erről szerzett tapasztalatok eredményeként sok pedagógus kifejezetten ellenzi ezeknek az eszközöknek az iskolai használatát. Valós veszélyként éli meg a pedagógus és a szülő is az úgynevezett mobilfüggőséget. Mindezek a tapasztalatok és félelmek a mobilok oktatási célú használatát blokkoló következménnyel járnak, s az elérhető tanítási-tanulási applikációk használatát idegenkedés és gyakran kifejezett tiltás akadályozza. A mobiltelefonoknak az oktatásba történő bevonása sok tényezőtől függ. Terras és Ramsay (2012) már sok évvel ezelőtt arra hívták fel a figyelmet, hogy a mobiltechnológiának a tanulásban történő sikeres alkalmazását befolyásolja az is, hogy a használt programok mennyire képesek a tanulókat lekötni, s ezzel a feladat iránti el- 
kötelezettségüket és koncentrációjukat növelni. Az oktatási célú applikációk fejlesztésének ezért fontos célja a tanulók motivációjának erősítése, fenntartása úgy, hogy a feladatok kialakításával a megismerő (kognitív) funkciók is fejlődnek. A tanulási célú mobilalkalmazás akkor sikeres, ha a figyelmi és emlékezeti rendszer kapacitásának fejlődését támogatja úgy, hogy az egyes tanulási területeken elengedhetetlenül fontos készségek elsajátíthatók, illetve fejleszthetők. Az egyik kiemelkedő tanulási terület az írás- és olvasáskészség elsajátítása, ilyen a finn kutatók által fejlesztett Graphogame, illetve más tanulási területre (például matematika) továbbfejlesztett Grapholearn. A mobilapplikáció használata a digitális kompetenciák fejlődésének kezdeti szakasza, s a mobiltechnológiával szembeni negatív attitűd a tudásszerzés új formáit akadályozza, s egyben növeli a digitális szakadékot ott, ahol a személyre szabott oktatásnak még ez a formája sem érhető el.

A digitális szakadék a hátrányos helyzet gyakori velejárója. Kim és munkatársai (2012) olyan matematikaijáték-alapú mobil intervenciós módszert dolgoztak ki, amelyet hátrányos helyzetü gyermekeknél próbáltak ki. Az eredmények azt mutatták, hogy a gyerekek a kognitív fejlődésben oly fontos felfedezés, felismerés, interakció és iteráció területén jelentős javulást mutattak. Teljesítményük javulásának mértéke település, nem és csoportméret szerint mutatott különbséget.

A mobiltechnológiák (okostelefon, táblagép stb.) oktatási célú alkalmazását elemző tanulmányok többsége arra hívja fel a figyelmet, hogy megfelelő oktatási környezetben, kifejezetten hasznos ezeknek a technológiáknak az alkalmazása. Ezek az eszközök egy korán, már kisgyermekkorban erősen ható motívumra, az ágencia motívumra támaszkodnak. Az ágencia motívum mozgatórugója a környezetre gyakorolt közvetlen hatás érzése, az adekvát tevékenységre adott reakció által kiváltott változás megélése. Ez indítja el, s további motívumok (kíváncsiság, koherens visszajelzés, siker stb.) tartják fenn az eszközzel végzett tevékenységet. Az így kialakuló rugalmas, differenciált, a figyelmet megragadó és lekötő tanulási környezet különösen fontos a kisiskolások számára. Ez ugyanis az önszabályozó, felfedező, a tudás konstrukcióját támogató tevékenység alapja. Összefoglalva megállapítható tehát, hogy a mobiltechnológiák többcélú alkalmazása, beépítése az oktatásba a motivált tanulás, valamint az általános és a tanulási területre specifikus kognitív képességek fejlesztésének egyik lehetséges útja.

\section{Tanulás és plaszticitás}

A tanulás programozza az agyat. Ez a természetes útja annak, hogy az agyi szerkezet és a müködés, informatikai hasonlattal élve a „hardver” és a „szoftver", egyaránt változzon. Az idegtudományban régóta jól ismert, hogy a tanulási tapasztalatok megváltoztatják az agynak azokat a funkcionális köreit, majd hálózatait, amelyek meghatározzák egy adott tanulási esemény feldolgozását és megjegyzését. A funkciók változásának alapja szerkezeti, azaz 
anatómiai átalakulás. Az elektronmikroszkópos felvételek jól mutatják, hogy a szinaptikus változások hatására az idegsejt rövid nyúlványain, a dendriteken kitüremkedések, úgynevezett „dendritikus tüskék” jelennek meg. Ezek mérete és száma a tanulási és emlékezeti folyamatoktól függ. Ezt az indukált változást úgy érdemes elképzelni, mint az információtárolás fizikai helyét. $\mathrm{Az}$, amit bármely ilyen dendritikus tüske tárol, nem más, mint az az aktivációs valószínűség, hogy a tüske olyan müködéseket generál, amelyek az emlékezeti tartalmak felidézésekor azokat a dendrittüskéket serkentik, amelyek az emlékezeti rögzülés során megnőtt aktivitást mutattak. Funkcionális szempontból ez a változás olyan, többé-kevésbé állandó jelleggel működő sablon, amely fontos mind az eredeti tanulási esemény felidézéséhez, mind pedig a jövőben előforduló hasonló eseményekre adandó válaszhoz. Természetesen nem egyetlen szinapszis felel az emlékezeti felidézésért és a tanulási hatásért, azaz az agy „programozásáért”, a tanulás és emlékezet az adott funkcionális körben megemelkedett szinaptikus müködés kollektív felerősödésének eredménye. A kialakult funkcionális sablonok lehetővé teszik, megkönnyítik a tanulást olyan új feladatoknál, amelyek hasonlóak. Ez az alapja az úgynevezett „tanulási készlet” koncepciónak, amelyet sok évtizeddel ezelőtt Harry Harlow (1949) írt le. A változásoknak ez az elemi szintje alapvetően befolyásolja az agy változási potenciálját, rugalmasságát.

Agyunk alapvető változásokon megy át tapasztalataink hatására, s ennek a változóképességnek, azaz az agyi plaszticitásnak különösen magas a szintje gyermekkorban. Ez különösen feltünő a csecsemő- és kisgyermekkorban. A fejlődés gyors változásokkal jár, és igen jelentős agyi plaszticitás jellemzi az élet első néhány évét (Barkovich et al., 1988). Jellemző ezen kívül az is, hogy egyes agyi területek plaszticitása kifejezettebb, mint másoké. Ilyen kiemelkedő plaszticitást mutató agyi terület például a hippokampusz (nevét a nyílirányú metszetben látható, tengeri csikóhalra emlékezetető alakjáról kapta), amely a tanulásban és az emlékezeti folyamatokban egyaránt érintett (Bliss \& Schoepfer, 2004; Pastalkova et al., 2006). Gyors és intenzív fejlődés és érés jellemzi az élet első három évét és a serdülőkort, s a plaszticitás azokban az életkori szakaszokban igen magas, amelyeket a nyelvi és a magasabb kognitív funkciók szempontjából jelentős változások jellemeznek. A serdülőkorban erőteljesen változó kognitív funkciók közül kiemelkednek a gondolkodás különböző formái, valamit a figyelmi és végrehajtó funkciók.

$\mathrm{Az}$ agy szerkezeti és funkcionális fejlődésének követésére alkalmazott mágneses rezonancia képalkotási (MRI) vizsgálatok ezeknek a funkcióknak a változásait kísérő változásokat mutattak ki a serdülő agyban (Crone \& Konijn, 2018). Az olyan funkciók javítása, mint a figyelem és a kognitív rugalmasság, valószínủleg a frontális és parietális lebeny vátozásának (mielinizáció és metszés) eredménye. A kisgyermekkor és a serdülőkor úgynevezett szenzitív szakaszaiban olyan kritikus érési, fejlődési és újraszerveződési folyamatok mennek végbe, amelyeket a tapasztalat és a környezeti hatások erősen befolyásolnak (Petanjek et al., 2011). 
Az agyi plaszticitás a tanulást lehetővé tevő alapfunkció, a változás egyik feltétele, így nem eredendően jó vagy rossz. A változás nagyságától és helyétől függően az eredmények eltérőek lehetnek. Azt is érdemes itt megjegyeznünk, hogy a gyakran használt hasonlat, azaz az agy újrahuzalozása valószínűtlen, a jelentős változások nem ebben nyilvánulnak meg (Mills, 2014).

Ezeknek a változásoknak a mérése azonban számos kérdés megoldását igényli. Például a funkcionális MRI-mérések során az agyi aktivitás követése indirekt, azaz nem közvetlenül a neurális aktivitás mutatói, hanem más változások (agyi vérátáramlás, oxigénkoncentráció) alapján történik. A nagyfelbontású aktivitásváltozás-térképek elsősorban azt mutatják meg, hogy az adott feladat végrehajtásában milyen agyi területek hálózata vesz részt, és ezek miben változnak, ha a feladatmegoldás feltételeit, összetevőit megváltoztatjuk. Mindez nem ad információt az egyes funkciók (azaz kognitív vagy viselkedési funkciók) alapjául szolgáló mechanizmusokról. Tudjuk tehát, hogy az alapmechanizmusok az agyi plaszticitáshoz kötődnek, de ezek és az agykérgi változások kapcsolatáról jelenleg nem tudunk még eleget. Az agykutatásban használt technikákkal mért jelenségek (agyi elektromos és mágneses aktivitás, képalkotást lehetővé tevő változások) ugyanakkor lehetővé teszik, hogy a szerkezetről és a funkcionális hálózatokról egyre pontosabb képet kapjunk. Ezek valódi funkcionális jelentőségére azonban igen nehéz következtetni, így a kutatások egy része feltáró szakaszban van.

A tanulás alapfolyamatainak és a kognitív funkciók agyi kísérőjelenségeinek tanulmányozása számos területen hozott új ismereteket. Ilyenek például az alapkészségek fejlődését és eltéréseit meghatározó agyi változások vizsgálatából származó adatok és az azokra épülő modellek. Az olvasás és szövegértés fejlődését, a korai matematika fö összetevőit, valamint a zenei nevelésnek az agyi hálózatok változásában mérhető hatását egyre jobban ismerjük. Ezek azok az eredmények, amelyeknek az oktatásban történő alkalmazását az oktatás-idegtudomány vizsgálja.

Az olvasáshoz, a zenéhez és a matematikai alapműveletekhez köthető agyi változásokat mintegy három évtizede követik igen nagyszámú idegtudományi kutatások. Ehhez képest a digitális technológiák használatára vonatkozóan úgyszólván alig vannak a tudományos vizsgálatokkal szembeni elvárásoknak megfelelő vizsgálatok. Bár a szakirodalom már egy évtizede összefüggésbe hozza a digitális technikák használatát az átmeneti (hangulat, éberségi állapot stb.) változásokkal és a hosszabb távú agyi és/vagy viselkedéses hatásokkal, ezek többsége a számítógépes játékok, mindenekelőtt a játékfüggőség hatásait követi. Bavelier, Green \& Dye (2010) összefoglaló tanulmánya óta egy évtized telt el, s ezalatt jelentősen megnőtt a digitális technológiák szerepe a mindennapokban és az oktatásban is, mégis ezek hatását alig vizsgálja tudományos igényủ kutatás. 


\section{Digitális oktatás, virtuális valóság és az agy}

A digitális oktatás hatásainak elemzéséhez leginkább azok az adatok érdekesek, melyek azt a feltételezést hívatottak vizsgálni, mely szerint az 1980 után született fiatalok egészen másként használják az okoseszközöket. Ennek tapasztalatai egyrészt az ő tevékenységük megértését szolgálják, másrészt megmutatják, hogy az igen korán használatba vett eszközök miként hatnak a kognitív fejlődésre. A vizsgálatok során a kutatók (pszichológusok, szociológusok és a társtudományok más területeinek művelői) a teljesítményt mérik, s ehhez gyakran kérdőíveket vagy más teszteket használnak, az adatokon pedig komplex, statisztikai elemzéseket végeznek, illetve azokhoz modelleket illesztenek. Amit ezek többségükben bizonyítottak, az az, hogy a kérdés közel sem olyan egyszerü, mint ahogyan arról sokan vélekednek. Egy török tanulmány alapját egy olyan kutatás képezte, amelynek során több száz egyetemistát vizsgáltak a különböző eszközöket alig, illetve gyakran használók köréből. Az eredmények szerint a digitális készségek korreláltak az oktatásban töltött évek számával, az oktatási környezettel, a digitális eszközök használatának mértékével, a képzési terület technológiai elvárásaival, valamint a technológia használati gyakoriságával (Akrjayir, Dündar \& Akrjayir, 2016). Tehát önmagában nem az életkor az, amely meghatározza ezeknek az eszközöknek a kompetens használatát, vagyis ezek a fiatalok nem egyszerüen „digitális bennszülöttek", hanem a digitális világba tanulnak bele.

Fontos leszögezni, hogy a kompetencia nem egyszerüen az eszközök gyors kezelését jelenti, az csupán az első lépcső abban a folyamatban, amelynek kiteljesedéséhez tartozik a digitális állampolgárság is. A célra irányuló használat nem önmagában valósul meg, hanem egy kulturális keretbe ágyazva. Ezt a keretet pedig egyaránt jelenti a család, a társak és az iskolai rendszer. Fontos tehát feltennünk a kérdést, hogy kedvez-e a mai oktatási környezet a technológiát használó generációnak. Az általános és általánosító válasz a határozott nem. Ennek oka pedig az, hogy a tanítás és tanulás még mindig nincs igazán összhangban azzal, amit a digitális világ kíván a gyerekektől. Az új digitális tanrend tapasztalatai remélhetőleg erre is választ adnak majd.

A digitális világ azonban nem csak a kétdimenziós mobiltelefon-képernyőn vagy laptopon nyílik meg előttünk, már három dimenzióban is lehetőség nyílik a tanulás támogatására. A kérdés az, hogy ezek az új eszközök hogyan segítenek megérteni a digitális világot vagy a világot általában. Ehhez érdemes elképzelnünk egy, a valóságtól a totális virtualitásig terjedő dimenziót. Ennek egyik végén a valóság helyezkedik el a maga helyhez és időhöz kötött természetével, a másikon pedig az a virtuális valóság, amelyben a látvány mellett valamennyi más érzékleti információ virtuális, azaz nincs kötve a valós téri és idői korlátokhoz. Ezen a dimenzión félúton helyezhetjük el azt a kiterjesztett valóságot, amelyben a virtuális és valóságos elemek keveredve jelennek meg. Ha jobban belegondolunk a virtualitás felé való elmozdulás már a telefonnal elkezdődött. A helyhez nem kötött hang már egy, a valóságban létező téri korlátot hivatott 
áthidalni és ezzel virtuális közelséget teremteni. Ugyanez igaz a média téri és idői távolságot áthidaló eszközeire.

Ma a virtuális valóság egyik legkézenfekvőbb alkalmazása a nehezen elérhető vagy költséges környezetek szimulálása. Ez jelenik meg a különböző tréningek esetében is, ahol a munkára és az elvégzendő feladatokra való felkészítés során, azért, hogy a helyzet ismerős legyen és gyorsan, határozottan tudjunk lépni, először a kérdéses helyzeteket virtuálisan tudjuk lejátszani akár többszáz alkalommal.

Kérdés azonban, hogy a virtuális valóság szükséges alkalmazás-e az oktatásban. Az is kérdés, hogy ezekben a helyzetekben az emberi agy úgy müködik-e, mint ahogy egy valós környezetben. A kutatások egyik része ennek vizsgálatára irányul. Egy ilyen kísérlet létrehozása általában az adott környezetben - például egy gyalogos-átkelőhelyen - történő és lehetséges jelenségek felmérésével kezdődik. A fejlesztés olyan módon történik ezekben a munkákban, hogy a gyalogosok számára egy szimulátort készítenek. Ez azonban leggyakrabban egy kétdimenziós modell, és már itt fontos megjegyezni, hogy a kétdimenziós tér agyi feldolgozása jelentősen eltér a háromdimenziósétól. Sőt, nemcsak ebben van eltérés, hanem a tér nagyságában is. Kutatások kimutatták, hogy kis terekben (itt olyan kicsire gondolunk, mint egy asztal) az emberi agy jól fel tudja dolgozni a tárgyak nagyságát és a bezárt szögeket, viszont problémát jelent az irányok összevetése. Nagy terekben viszont ez könnyedén megy, helyette a bezárt szögek megjegyzése lesz nehézkes (Spelke, Lee \& Izard, 2010). Tegyünk csak egy próbát! Miután egy új várost térkép nélkül bejártunk, próbáljunk meg egy vázlatot készíteni róla, s látni fogjuk, hogy leggyakoribb hibánk az utak által bezárt szögek torzítása lesz.

A virtuális térben sokféle jelenséget sokféle módon lehet szimulálni. Számos érdekes irány mellett érdemes megemlíteni azokat az autizmus spektrumzavar területén elindult kutatásokat, amelyek virtuális térben végzett tréninggel kívánják a tanulást és a gyengén fejlett kommunikációs, társas készségeket támogatni. Yang és munkatársai (2017) például egy virtuális térben végzett társas kognitív fejlesztő programot használtak. A program használata közben fMRI eljárással követték a tréning hatásait, s azt találták, hogy jelentős változás azokon az agyterületeken volt mérhető, amelyek a virtuális térbeli helyzetben a társak mozgásához, kommunikációjához, tehát a társas kognícióhoz kapcsolódtak. Mindez arra utal, hogy a virtuális tér olyan szimulációs helyzetekben történő tréningre, fejlesztésre ad lehetőséget, amely a személyre szabott oktatásban is jól használható.

A szisztematikus idegtudományi kutatások azonban késlekednek. A legtöbb, bár a tanulás kognitív hátterének - figyelem, emlékezet, problémamegoldás, olvasás, idegen nyelv, matematika - idegtudományi vizsgálatához képest elenyésző mennyiségű adat a lehetséges és valós ártalmakhoz kapcsolódó agyi változásokról áll rendelkezésre. Ezek mindenekelőtt a függőségekhez (internet, számítógépes játék, okostelefon) kapcsolódnak, s nem az 
eszközök okos használatával támogatott tanuláshoz köthető agyi változások feltárásához. Ennek valószínű oka, hogy az okoseszközök elterjedésével nem foghatók meg jól a változók, nincs specifikus, kizárólag az eszközhasználathoz köthető hatás, s ezért világosan megragadható, egyértelműen egyes tényezőkhöz köthetően elkülöníthető csoportok sincsenek. A digitális eszközök használatával feltehetően a tanulásnak azok a komponensei erősödnek meg, amelyek agyi korrelátumait viszonylag jól ismerjük. Ebből következően az okoseszközök használatával járó agyi változásoknak ma nincs szisztematikus kutatása, az egyes tanulmányokban elérhető elemzések pedig a tanulás agyi korrelátumaira támaszkodó, közvetlen mérést nélkülöző következtetések. Igaz ez arra a területre is, amely az aktív tanulás egyik egyre jobban terjedő módszere, a gamifikáció, azaz a számítógépes játékok elveit követő oktatási program.

Zainuddin és munkatársai (2020) tanulságos szakirodalmi áttekintést adnak 46 olyan empirikus kutatási dokumentum tematikus és tartalomelemzésével, amelyet 2016 és 2019 között tettek közzé a Web of Science adatbázisában. A kutatási adatok értékelése, a feltárt ellentmondások elemzése a jövőbeli kutatások fontos szempontjaira irányítja a figyelmet. Ezek a fentiekben leírtakat igazolják, nevezetesen azt, hogy elsőként a módszer, itt a gamifikáció elméleti alapjait, módszertani megközelítéseit, elméleti modelljeit kell világossá tenni. Szükséges továbbá a játékplatformok és alkalmazások összehasonlítása, a játékban érintett tanulási formák, kognitív faktorok és a tanulási eredmények elemzése. A tanulmány ezért nem csak arra próbál rávilágítani, hogy milyen újdonságot jelent a gamifikált, a motiváció, a bevonódás és a felhasználói élmény kulcsfontosságú változásait előhívni hivatott tanulás. A szerzők komoly elemző munkát végeztek annak érdekében is, hogy hitelesen mutassák be a gamifikáció legfontosabb kihívásait és akadályait. Ez fontos a módszerek értékelése és bevezetése szempontjából egyaránt. Egyértelmủ ezért, hogy a felsoroltak feltárása, azonosítása nélkül sem a gamifikáció, sem más digitális pedagógiai módszer komoly idegtudományi vizsgálata nem várható. Addig is, amíg erre sor kerül, érdemes a tanulás meghatározó tényezőire vonatkozó idegtudományi adatok alapján a digitális eszközökkel támogatott tanulásra következtető tanulmányokat kritikai távolságtartással kezelni.

\section{Köszönetnyilvánítás}

A tanulmány elkészültéhez az EFOP-3.2.15 VEKOP-17-2017-00001 „A köznevelés keretrendszeréhez kapcsolódó mérési-értékelési és digitális fejlesztések, innovatív oktatásszervezési eljárások kialakítása, megújítása" elnevezésű projekt tartalomfejlesztési alprojektje (szakmai vezető az első szerző) biztosított támogatást. 


\section{Irodalom}

Akçayır, M., Dündar, H., \& Akçayır, G. (2016). What makes you a digital native? Is it enough to be born after 1980? Computers in Human Behavior, 60, 435-440. https://doi.org/10.1016/j.chb.2016.02.089

Barkovich A. J., Kjos B.O., D E Jackson D. E., \&, Jr Norman D. (1988), "Normal maturation of the neonatal and infant brain: MR imaging at 1.5 T., Radiology, 166(1), 173-180. https://dx.doi.org/10.1148/radiology.166.1.3336675

Bavelier D., Green C., \& Dye M. (2010). "Children, Wired: For Better and for Worse”, Neuron, 67(5), 692-701. http://dx.doi.org/10.1016/J.NEURON.2010.08.035

Bliss T., \& Schoepfer, R. (2004). "NEUROSCIENCE: Controlling the Ups and Downs of Synaptic Strength”. Science, 304(5673), 973-974. https://dx.doi.org/10.1126/ science.1098805.

Blikstad-Balas, M. (2015). Digital literacy in upper secondary school-what do students use their laptops for during teacher instruction? Nordic Journal of Digital Literacy, 10 (Jubileumsnummer), 122-137. https://www.idunn.no/ $\mathrm{dk} / 2015 /$ Jubileumsnummer/

Bloom, B. S. (1984). The 2 sigma problem: The search for methods of group instruction as effective as one-to-one tutoring. Educational Researcher, 13(6), 4-16. https://www.jstor.org/stable/1175554

Crone E., \& E. Konijn (2018). "Media use and brain development during adolescence". Nature Communications, 9(1), 588. https://dx.doi.org/10.1038/s41467-01803126-x.

Harlow, H. F. (1949). The formation oflearning sets. PsychologicalReview, 56(1), 51-65. https://doi.org/10.1037/h0062474

Kim, N. J., Belland, B. R., \& Walker, A. E. (2017). Effectiveness of Computer-Based Scaffolding in the Context of Problem-Based Learning for Stem Education: Bayesian Meta-analysis. Educational Psychology Review, 1-33. https://doi. org/10.1007/s10648-017-9419-1

Kim, P. Buckner, E. Kim, H. Makany, T. Taleja, N., \& Parikh, V. (2012). “A comparative analysis of a game-based mobile learning model in low-socioeconomic communities of India”. International Journal of Educational Development, 32(2), 329-340. http://dx.doi.org/10.1016/j.ijedudev.2011.05.008

Mills, K. (2014). "Effects of Internet use on the adolescent brain: despite popular claims, experimental evidence remains scarce". Trends Cogn Sci., 18(8), 385-387. http://dx.doi.org/10.1016/j.tics.2014.04.011.

Pastolkava, E., Peter Serrano P., Pinkhasova, D., Wallace, E., Fenton, A. A., \& Sacktor T. C. (2006). "Storage of Spatial Information by the Maintenance Mechanism of LTP”, Science, 313(5790), 1141-1144. http://dx.doi.org/10.1126/science.1128657.

Petanjek, Z., Judaš, M., Šimić, G., Rašin, M. R., Uylings, H-B-M., P. Rakic, P., \& Kostović, I. (2011). "Extraordinary neoteny of synaptic spines in the human 
prefrontal cortex.", Proceedings of the National Academy of Sciences of the United States of America, 108(32), 13281-13286. http://dx.doi.org/10.1073/ pnas.1105108108.

Spelke, E., Lee, S. A., \& Izard, V. (2010). Beyond core knowledge: Natural geometry. Cognitive Science, 34(5), 863-884. https://doi.org/10.1111/j.15516709.2010.01110.x

Taylor, D. (2007). Death by PowerPoint. Developmental Medicine E Child Neurology, 49(5), 395. https://doi.org/10.1111/j.1469-8749.2007.00395.x

Terras, M. M., \& Ramsay, J. (2012). The five central psychological challenges facing effective mobile learning, British Journal of Educational Technology, 43(5), 820-832. http://dx.doi.org/10.1111/j.1467-8535.2012.01362.x

Yang, Y. J. D., Allen, T., Abdullahi, S. M., Pelphrey, K. A., Volkmar, F. R., \& Chapman, S. B. (2017). Brain responses to biological motion predict treatment outcome in young adults with autism receiving virtual reality social cognition training: preliminary findings. Behaviour Research and Therapy, 93, 55-66. https://doi. org/10.1016/j.brat.2017.03.014

Zainuddin Z., Wah Chu S. K., Shujahat M., \& Perera C. J. (2020) The impact of gamification on learning and instruction: A systematic review of empirical evidence. Educational Research Review, 30, 100326. shttps://doi.org/10.1016/j. edurev.2020.100326 


\section{Csépe, V. \& Török, Á.}

\section{Usage of smart devices from the perspective of cognitive sciences}

The authors review those cognitive factors whose changes underpin the use of smart devices and present the educational opportunities and challenges of the 21 st century. The review covers the early stages of using digital devices, the potential benefits, obstacles and dangers of using smartphones. The analysis is based on the description of basic neuronal changes during learning and provides an overview of the conditions and correlational factors necessary for systematic and rigorous research to shed light on the brain changes that accompany the use of smart devices. The reliability of data and models based on the study of brain changes that determine the development and deviations of basic skills, highlighted by authors in reading, early mathematics and music education, show a number of examples of why only a few reliable neuroscientific data are available on learning assisted by smart devices. Specifically, the study puts an extra emphasis on those factors that contributed to the limited knowledge about the impact of digital teaching methods, especially the use virtual reality and gamification, on the brain networks' changes as compared to the other factors of learning.

Keywords: smart phone, virtual reality, gamification, brain plasticity

Csépe Valéria: https://orcid.org/0000-0002-5021-6024 